\title{
Formation of Lingual Identity in Preschool Institutions of the Republic of Tatarstan
}

\author{
Alsou Moudarisovna Gareeva ${ }^{1}$ \\ ${ }^{1}$ Kazan (Volga) Federal University, Institute of psychology and education, Department of psychology of \\ preschool education, Kremlevskaya st., 18, Kazan, Russian Federation \\ Correspondence: Alsou Moudarisovna Gareeva, Kazan (Volga) Federal University, Institute of psychology and \\ education, 1 Martyn Mezhlauk St., Kazan, 420111, Russian Federation. E-mail: alsoukgpu@mail.ru
}

Received: August 24, 2014 Accepted: September 7, 2014 Online Published: November 27, 2014

doi:10.5539/ass.v10n24p231 URL: http://dx.doi.org/10.5539/ass.v10n24p231

\begin{abstract}
In the Republic of Tatarstan (Russian Federation) we meet with a certain discrepancy when deal with the problem of lingual identity formation. Therefore the outcomes of coordinated (synchronous, simultaneous) teaching of Russian, Tatar and English languages to preschool level children are to be analysed. In Tatarstan it emerged, on the one hand, from the need to learn three languages rather than two, i.e. Tatar, Russian and English languages at an active speaking level. The problems of lingual identity formation in preschool institutions of the Republic of Tatarstan are depicted. The research showed that children relatively easily and quickly remember the words, learn to use them in their speech, show their interest in differences between the languages. If in the course of the second stage of research $40 \%$ of children got high score, then during the third stage $80 \%$ revealed good knowledge, which makes the majority of the group. Children recognize familiar words, can name the things, try to make sentences in all three languages. It's quite natural, that not all children can master language material, but there's a tendency that answers of all children become more confident and precise to the third stage of research.
\end{abstract}

At the first stage, children did not understand the difference between the languages. At the second stage children confused languages, made mistakes in their answers, while at the third stage there were far less mistakes.

Monitoring is very important in teaching languages, since it allows to estimate the level of mastering language material, to define group of children who feel it difficult to learn languages in order to carry out additional work on subject revision.

Key words: lingual identity, coordinated, polycultural, bilingual, trilingual education, preschool level

\section{Introduction}

In the Republic of Tatarstan (Russian Federation) we meet with a certain discrepancy when deal with the problem of lingual identity formation. In Tatarstan it emerged, on the one hand, from the need to learn three languages rather than two, i.e. Tatar, Russian and English languages at an active speaking level. On the other hand, it is related with lack of courseware for coordinated trilingual education. Tatar and Russian languages are official languages in the Republic of Tatarstan, they are studied both by the Tatars and Russians. At the same time, due to the increased international activity of Tatarstan, there appeared a strong need in good command of one of European languages (English, French or German). In case if study of three languages is in-coordinated, during communication child absorbs a noun, for example, in Russian, a verb-in English, and the whole sentence-in Tatar language. This would have an adverse effect on the results of learning all three languages. The matter is that motivational aspects of child's lingual identity formation are not taken into account. (Gabdulchakov, 2011) Such important linguistic phenomena, such as positive transfer (transposition) and adverse effect (interference) of one language to another are also disregarded.

At the present moment, much attention is paid to polycultural education, since life in multinational society provides for communication and interaction of people who speak different languages and have special way of life. Recent research prove that cognition of bilingual children is better developed in the result of information penetration by means of two different languages (Hamers \& Blanc, 1989). Polycultural education allows students to develop language skills, contributes for teambuilding and interpersonal relationships strengthening (Martyniuk, 2011). Besides, the growing emigration level makes businessmen look for employees who can speak 
several languages (Hamilton-Wright, 2005). The government tries to give support to those who study languages at school (Skutnabb-Kangas, 2000).

Now practically in all countries much attention is paid to polycultural education development. But each region has its specific living conditions, certain ethnic composition, that's why aims of polycultural education are unique for each country, and consequently, the work in this direction shall be planned in different ways. In other words, there's no universal programme of polycultural education, which would suit for all countries or for all regions of a single country. Even if a certain programme meets requirements of several regions, nevertheless it would take a certain correction of its contents. We can agree with Yuko Goto Butler's statement “....both global and local factors influence policy decisions and their implementation in very complex ways. While the education policies in the three countries discussed herein faced certain common challenges, they also entailed different views towards English as a foreign language at Primary schools and frequently incorporated different approaches within their respective local contexts. Directly importing popular English language teaching methodologies does not seem to work well without making major adjustments to account for the local educational contexts. Indeed, successful implementations do not appear to be possible without giving serious consideration to local factors". (Butler, 2009)

Thereat some requirements concerning polycultural education may be important for many regions. For example, success criteria of bilingual programmes in the USA, concerning which Calderon and Carreon state, that the minimal period of bilingual training should be from four to six years, academic contents shall not differ from other educational programmes, teaching and independent work of students shall held be in two languages, the learned language should be used for at least $50 \%$ and so on (Calderon \& Carreon, 2000). Such requirements are general and may be used for polycultural education programme development by any educational institution, irrespective of the region's national, geographic or sociological factors. In 2003 Ovando, Collier and Combs undertook a study and came to a conclusion, that the more students know about other cultures and interact with them, the less prejudice they would have in future. Such outcomes are not place-specific, but have a universal character (Ovando et al., 2003).

In ELT Research Papers we can see some general requirements concerning teaching young learners, material should be "resource-light to accommodate contexts, where there may be limited funding, facilities or equipment, accompanied by full and simple instructions in order to assist teachers to use them effectively, imaginative, and draw on local cultural understandings, creative, to increase students' confidence in using English, aimed at motivating young learners to learn English". (Garton et al., 2011)

Guided by Professor of Kazan Federal Universdity Gabdulkhakov V. F., on the grounds of teachers' experience and research findings, methodical guidelines have been developed for game-based linguistic development of children in preschool institutions of the Republic of Tatarstan. The peculiarity of educational system in the Republic of Tatarstan is the need for trilingual education: Russian, Tatar and English. (Gareeva \& Danilova, 2012)

It is well known, that game is the main activity of preschool children that is why teaching languages, study of cultural values shall be carried out in the form of game.

Methodical guidelines are aimed at simultaneous teaching of Russian, Tatar and English languages to preschool children. On the grounds of the said aim, the following tasks have been defined:

- To develop trilingual speech;

- To develop memory;

- To acquaint children with the learned languages culture;

- To broaden their outlook;

- To help to recognize child's place in the world around.

Various didactic demonstrational and handout materials are used in the process of training and education for a better and faster understanding of information and vocabulary. There may be used most diverse teaching methods. Besides the main game, phonetic exercises, finger games, the P.T. breaks, recitation of poems and rhyming, talks, individual, group and frontal work may be applied.

Audio equipment and interactive boards are used as technical aids.

Work on teaching languages and learning cultural elements has a module structure. The material has been grouped in three language modules. The first module is Russian language, which is the state language of the Russian Federation, the second module is Tatar language, which is the second state language of the Republic of 
Tatarstan, and the third is English language as language of international communication. Each module has its representative, for a better communication the characters are given names: Toptyzhka Bear (Мишка-Топтыжка), Amina Squirrel (Тиен Әминә), Robert Hare. This allows to provide a clear demarcation of works and helps children to shift from one language to another, to lessen the confusion between languages.

The study of languages is coordinated and parallel, that means that material studied in one module is presented in another module in appropriate language. Such form of work helps to save time spent on explanation of game rules, translation of vocabulary, because children get major information when they work with the first module of Russian language. The contents of the second and third modules are laid on the basis of the first module.

In the process of training and education, much attention is paid to interaction with parents, because of parents' direct and indirect effect on child's intellectual and social development (Desforges \& Aboochaar, 2003), parental care is a complex, comprehensive and flexible mechanism that has different forms and is subject to changes (Issari, 2013). That is why it is so necessary to explain to parents all benefits of polycultural education for achievement of better results.

\section{Materials and Methods}

To get the most full and exact picture of language material, a package of assignments in different spheres have been developed. The results are estimated on a 1-10 scale. During the research, it is necessary to pay attention to time and exactness of answers in each language.

In the first assignment, children are offered to listen dialogues in one of three languages. The task is to determine the language of the dialogue. Answer correctness and time should be taken into account.

Second, children are offered cards depicting objects on the learned topics. Children in turns perform a task. The child is asked to show a certain thing given in one of three languages.

The third assignment supposes logical games "Two is company, three is none", when children should name odd thing in a certain language in terms of some characteristic feature.

In the fourth assignment, game situations are given in one of languages, and children should dialogue on a certain topic. Knowledge of vocabulary, sentence making, understanding of communicator are estimated.

The fifth assignment offers children to play games in one of languages. Knowledge of rules, cadences, activity in game are estimated.

15 children of preschool level took part in research. Research was held in several stages. First, knowledge was estimated in the very beginning of polycultural education (children aged 4-5 years), for the second time-after one year of education (children aged 5-6 years), for the third time-after two years of training (children aged 6-7 years). As supposed, children in the beginning of training had elementary knowledge, but the fulfilment of fourth and fifth assignments without preparatory training was inadvisable, that's why their results were excluded during finalizing of findings.

Due to extensive research material, age of children, the need in individual work with children to obtain more precise results, the experimentation took nearly two weeks. The work has been held frontally, individually and in groups. More active children required less time than even-tempered, inert ones.

At the first stage, cards depicting some things were laid on the table in front of children, so that they could pick them. At the second stage cards for the second assignment were put on the table, and for the third assignment-on the board, because children became older, they had a far more developed abstractive and logical thinking.

\section{Results}

During the first research year, held in November, 2011, the following results have been obtained: the first task was accomplished by 7 children to $8-10$ grades, which is $46.7 \%, 3$ children-to $5-7$ grades, which is $20 \%, 5$ children got less than 5 grades, which makes $33.3 \%$.

The second assignment revealed the following results:

3 children got 8 - 10 grades, $20 \%$.

6 children got 5-7 grades, $40 \%$.

6 children got less than 5 grades, $40 \%$.

The third assignment showed as follows:

2 children got $8-10$ grades, $13.3 \%$. 
6 children got 5-7 grades, $40 \%$.

7 children got less than 5 grades, $46.7 \%$.

The second stage of research was held in May, 2012, at that time children during academic year had studied three languages parallel to each other. The results are as follows:

Table 1. Outcomes of the second stage of research May, 2012; grades (gr.), children (ch.), assignment (as.)

\begin{tabular}{lllllll}
\hline & 1 as. & 2 as. & 3 as. & 4 as. & 5 as. & Mean value \% \\
\hline 8-10 gr. & $10 \mathrm{ch}$. & 6 ch. & 5 ch. & 4 ch. & 8 ch. & 40 \\
$5-7$ gr. & 2 ch. & 6 ch. & 4 ch. & 8 ch. & 4 ch. & 33.3 \\
Less Than 5 gr. & 3 ch. & 3 ch. & 6 ch. & 3 ch. & 3 ch. & 26.7 \\
\hline
\end{tabular}

The third stage of research was held in May, 2013. The results as follows:

Table 2. Outcomes of the third stage of research. May, 2013; grades (gr.), children (ch.), assignment (as.)

\begin{tabular}{lllllll}
\hline & 1 as. & 2 as. & 3 as. & 4 as. & 5 as. & Mean value \% \\
\hline $8-10$ gr. & 14 ch. & 10 ch. & 11 ch. & 9 ch. & 12 ch. & 80 \\
$5-7$ gr. & 1 ch. & 3 ch. & 2 ch. & 4 ch. & 2 ch. & 13.3 \\
Less Than 5 gr. & 0 & $2 \mathrm{ch}$. & $2 \mathrm{ch}$. & $2 \mathrm{ch}$. & $1 \mathrm{ch}$. & 6.7 \\
\hline
\end{tabular}

\section{Discussion}

In 2011 ELT Research Papers which was made in collaboration with Aston University we can find the conclusion that an expanded range of materials for teaching young learners is needed. "Materials development and their use should become a key area for research and development in the field. Materials need to be available in as many formats as possible to respond to local conditions. Possible formats include paper-based, CD-ROM, internet, and local media such as radio". (Garton et al., 2011)

$\mathrm{X}$. Wu demonstrated that “...providing young second language learners with a predictable learning environment, moderately challenging tasks, necessary instructional support, and evaluation that emphasizes self-improvement are effective ways of developing students' perceived competence, while giving them freedom in choosing the content, methods and performance outcomes of learning, as well as providing integrative strategy training lead to enhanced perceived autonomy." (Wu, 2003)

Peter Edelenbos, P. Richard Johnstone, \& Angelika Kubanek in the article the main pedagogical principles underlying the teaching of languages to very young learners. Languages for the children of Europe stated that "...there is no automatic way of achieving good practice, be it at the organizational, the teacher-training or classroom level. Therefore neither the examples nor this part of the conclusions should be read quantitatively or with an if-then attitude. The motivation and learning success of the children cannot be predicted by ticking 10 instead of 7 quality indicators in a checklist. Nor is it possible to predict good practice in an uni-directional way, stating that success is guaranteed if $\mathrm{x}, \mathrm{y}$ and $\mathrm{z}$ conditions are fulfilled. Creating and even improving good practice occurs as interplay of factors through negotiations and interpretations as a process over time." (Edelenbos et al., 2006.)

In 2006 Richards Jack analyzed current communicative language teaching theory and practice and he found out that "...thus draws on a number of different educational paradigms and traditions. And since it draws on a number of diverse sources, there is no single or agreed upon set of practices that characterize current communicative language teaching. Rather, communicative language teaching today refers to a set of generally agreed upon principles that can be applied in different ways, depending on the teaching context, the age of the learners, their level, their learning goals, and so on. The following core assumptions or variants of them underlie current practices in communicative language teaching."(Richards, 2006)

J. Enever's research indicated “...the importance of adopting a multidisciplinary approach to the study of ELL policy, not relying only on applied linguistics, but also drawing on the fields of education, social policy and economics." (Enever, 2009) 
Psycholinguistic research methods in teaching languages got widespread application today. The main attention is paid to monitoring of language material learning. Methodology of the process of teaching languages to children has been developed (Sekerina, 2008), characteristic features of practical use of psycholinguistic methods have been described and main operating instruments have been offered (Jegerski \& Van Pattern, 2013). Psycholinguistic directions have been considered, the role of sociolinguistic speech stereotypes have been studied (Loudermilk, 2013). The research showed that answering time and speech automation are very important factors in learning languages that is why special attention should be paid to them in teaching spoken language (Van Moere, 2012).

A biggest and most developed group of methods, a so called behavioral, is distinguished among psycholinguistic methods, since such methods give most exact results in work with preschool level children. To study effectiveness of polycultural education, it is recommended to monitor several times the outcomes of language learning.

\section{Conclusion}

The research showed that children relatively easily and quickly remember the words, learn to use them in their speech, show their interest in differences between the languages. If in the course of the second stage of research $40 \%$ of children got high score, then during the third stage $80 \%$ revealed good knowledge, which makes the majority of the group. Children recognize familiar words, can name the things, try to make sentences in all three languages. It's quite natural, that not all children can master language material, but there's a tendency that answers of all children become more confident and precise to the third stage of research.

At the first stage, children did not understand the difference between the languages. At the second stage children confused languages, made mistakes in their answers, while at the third stage there were far less mistakes.

Monitoring is very important in teaching languages, since it allows to estimate the level of mastering language material, to define group of children who feel it difficult to learn languages in order to carry out additional work on subject revision.

Intensive work on teaching three languages to preschool children allows to better develop child's language abilities, enriches vocabulary, develops memory, allows to systematize knowledge, learn languages in comparison. All of the above creates conditions for a new type lingual identity formation-a communicative, polycultural identity, acquaint with universal human values.

\section{References}

Butler, Y. (2009). Teaching English to young learners: The influence of global and local factors. Young Learner English Language Policy and Implementation: International Perspectives (pp. 23-29). Reading, UK: Garnet Education.

Calderon, M., \& Carreon, A. (2000). A Two-Way Bilingual Program: Promise, Practice, and Precautions: Report. Baltimore, MD: Center for Research on the Education of Student Placed at Risk.

Desforges, C., \& Abouchaar, A. (2003). The impact of parental involvement, parental support and family education on pupil achievement and adjustment: A literature review. London: Department for Education and Skills.

Edelenbos, P., Johnstone, R., \& Kubanek, A. (2006). The main pedagogical principles underlying the teaching of languages to very young learners. Languages for the children of Europe. Published Research, Good Practice and Main Principles. Final Report of the EAC 89/04, Lot 1 study. European Commission, Brussels: Education and Culture, Culture and Communication, Multilingualism Policy.

Enever, J. (2009). Why applied linguistics is not enough. Contemporary early foreign language learning policy in Europe: A critical analysis. London: BAAL Proceedings 2008.

Gabdulchakov, V. F. (2011). Of linguistic education in kindergartens. International Journal of Early Years Education, 19(2), 185-188. London: Rout ledge.

Gareeva, A., \& Danilova, Z. (2012). In V. F. Gabdulkhakov (Ed.), Game lessons for language development of children. 4-5 years old children. Moscow: National Book Centre.

Garton, S., Copland, F., \& Burns, A. (2011). Investigating Global Practices in Teaching English to Young Learners. ELT Research Papers, 1-11. London: British Council.

Hamers, J., \& Blanc, M. (1989). Bilinguality and Bilingualism. Cambridge: Press Syndicate of the University of Cambridge. 
Hamilton-Wright, K. J. (2005). Increase job opportunities, become bilingual. Miami: Miami Times.

Issari, P., \& Karayianni, T. (2013). Greek Mothers' Narratives of the Construct of Parental Involvement. The European Journal of Counselling Psychology, 2(1), 17-32. http://dx.doi.org/10.5964/ejcop.v2i1.3

Jegerski, J., \& Patten, B. V. (2013). Research Methods in Second Language Psycholinguistics. London: Rout ledge.

Loudermilk, B. C. (2013). Psycholinguistic Approaches. The Oxford Handbook of Sociolinguistics (pp. 132-152). Oxford: Oxford University Press.

Martyniuk, W. (2011). In support of plurilingual people living in multilingual societies: Policies and frameworks of European language education. Cashiers De L'ILOB, 2, 1-17. GRAZ: Council of Europe, European Centre For Modern Languages.

Ovando, C. J., Combs, M. C., \& Collier, V. P. (2006). Bilingual and ESL classrooms: Teaching in multicultural contexts (4th ed.). New York: McGraw-Hill.

Richards, J. (2006). Communicative language teaching today. Cambridge: Cambridge University Press.

Sekerina, I. A., Fernández, E. M., \& Clahsen, H. (2008). Developmental psycholinguistics: On-line methods in children's language processing. Amsterdam: John Benjamins Pub. http://dx.doi.org/10.1075/lald.44

Skutnabb-Kangas, T. (2000). Linguistic genocide in education-or worldwide diversity and human rights? Mahwah: Lawrence Erlbaum Associates.

Van Moere, A. (2012). A Psycholinguistic Approach to Oral Language Assessment. Language Testing, 29, 325-344. http://dx.doi.org/10.1177/0265532211424478

$\mathrm{Wu}, \mathrm{X}$. (2003). Intrinsic motivation and young language learners: The impact of the classroom environment. System, 31(4), 501-517. http://dx.doi.org/10.1016/j.system.2003.04.001

\section{Copyrights}

Copyright for this article is retained by the author(s), with first publication rights granted to the journal.

This is an open-access article distributed under the terms and conditions of the Creative Commons Attribution license (http://creativecommons.org/licenses/by/3.0/). 